\title{
Neotropical seasonally dry forests: response of soil fungal communities to anthropogenic actions
}

\begin{abstract}
The aim of this review was to analyze the information available on soil fungal community of Neotropical Seasonally dry forests, with special attention given to the Chaco area. This review is focused on the loss of soil fungal community due to anthropogenic actions such as forest clearing. Over the last decades, the expansion of the agricultural frontier has had a wide range of physical, chemical and biological effects on Neotropical dry forests. As these changes on the Schinopsis dry forests (Chaco) have rendered the ecosystem vulnerable, these areas have become some of the few protected areas in South America. After analyzing both national and international studies to find the latest research available on the topic we have noticed there is lack of specific studies on soil fungal community in the Chaco area, unlike Cerrado and Caatinga where most studies have been carried out. Therefore, we propose to conduct more in-depth studies on soil fungi in Schinopsis forests to revalue the Chaco fungal community to use them as potential indicators of soil health and to develop new management techniques.
\end{abstract}

Keywords: soil fungi, dry forests, land use, clearing, management
Volume 2 Issue 2 - 2018

\author{
Merlos Cristina Soledad,' Pelizza Sebastián \\ Alberto, ${ }^{2}$ Moreno María Virginia' \\ 'Laboratory of Functional Biology and Biotechnology \\ (CONICET-INBIOTEC-CICBA), National University of Central \\ Buenos Aires, Argentina \\ ${ }^{2}$ National University of La Plata, Argentina
}

Correspondence: Moreno María Virginia, Agronomy faculty, Laboratory of Functional Biology and Biotechnology, National University of Central Buenos Aires, República de Italia N78, Tandil, Buenos Aires, Argentina,

Email vmoreno@faa.unicen.edu.ar

Received: February 28, 2018 | Published: April 16, 2018

\section{Introduction}

Different terrestrial ecoregions ranging from deserts to tropical forests $^{1}$ exist around the world. One of them, Neotropical dry forests (NTDFs) play an important role in the economic and cultural development ${ }^{2}$ and according to $^{3}$ the forest is one of the main sources of carbon (C). Van der Werf et al., ${ }^{4}$ pointed out that the loss of C due to anthropogenic effects accounts for $12 \%$. Becknell et al., 5 suggested that if tropical and Neotropical dry forests were restored, they would comprise $22 \mathrm{Pg}$ of carbon in aboveground biomass and in the Americas alone, the contribution of carbon could be of $8 \mathrm{Pg}$. In the last decades, the studies on NTDFs have been focused on the diversity of plants, animals and $\mathrm{C}$ storage. ${ }^{6}$ This shows an increase in our awareness of biodiversity, carbon and water only in secondary forests at local scales.

Forest diversity was one of the issues of Sustainable Forest Management addressed by the General Assembly of the United Nations. ${ }^{7}$ The loss of diversity has dramatic effects not only on the forest ecosystem services but also on science, development and knowledge. While the NTDFs are considered one of the most vulnerable forests, the existing scientific research on this habitat is scarce. ${ }^{8}$ Over the last decades and due to the expansion of the agricultural frontier the studies on NTDFs have increased. ${ }^{9}$ However, the studies in other areas in Central and South America are still poor or unknown. Within these areas the Neotropical seasonally dry forests (NTSDFs) ${ }^{10}$ are relevant to socio-economic development and according to Miles et al., ${ }^{11}$ the NTSDFs are the most vulnerable forests in the world. The seasonally dry forest in South America is known as Gran Chaco. ${ }^{10}$ It has favorable environmental conditions for the implantation of cultivars and technological improvements that have led to the conversion of woody vegetation into areas managed purely for agricultural crops. In addition, this region experienced a decline in the rural population. ${ }^{12}$ The advance of agroforestry in the Chaco in the 1980s accelerated the clearing of large tracts of forests and shrublands and this is currently continuing. ${ }^{13}$ This affects the structure and functionality of ecosystems,${ }^{14}$ which leads to habitat degradation, thus affecting the ecological conditions of forests. ${ }^{15}$ The Chaco forests are a clear example of deforestation driven by the expansion of agroindustry. ${ }^{16}$

Soil diversity is a relevant component of ecosystem services considering that soil microorganisms play essential roles in biogeochemical cycles. Fungi are components of soil microbiota. However, little is currently known about the functioning and diversity of forest soil fungi despite the fact that they are the fundamental links of ecosystem functioning in native forests and they are relevant elements to create sustainable agriculture supply chains. The application of molecular techniques has allowed the identification of a bigger fraction of species from different substrates especially in soil. ${ }^{17,18}$ In 2007 mycologists and scientists revealed that the Kingdom Fungi accepts one subkingdom Dikarya and seven phyla. ${ }^{19}$ The number of species known at the moment is 1.5 million and the estimated range is from 2.2 to 3.8 million species..$^{20}$

Soil fungal communities in different forests have been studied. ${ }^{21-25}$ All studies have shown that deforestation alters the soil microbial community, ${ }^{26}$ and the vegetation structure has been cited as a major source of variation on the soil community. ${ }^{22,23}$ However, we should not overlook the environmental factors that drive the composition and abundance of soil fungal communities. In the same way, the plant community composition has been suggested as a source of variation in soil fungal diversity. ${ }^{27,28}$

It stands to reason that future studies should address different soil management practices to favor the biota preservation as a means of increasing production in agroecosystems. In this point, we suggest that as fungi are involved in diverse biological activities, they can act as indicators of the environmental deterioration and could provide us with information about soil health..$^{29,30}$ The diversity of soil fungal communities at different environmental levels, according to the plant species that are present, provides information about the ecological functionality of these organisms in soil. ${ }^{31}$ Jangid et al., ${ }^{29}$ suggested that 
the soil community in modified native forest and native forest soils was similar after 50 years. This indicates that the recovery of ecosystems is noticeable to human beings although similar concentrations of $\mathrm{C}$ and $\mathrm{N}$ were detected among forests after 50 years. ${ }^{32}$

The information available varies noticeably across regions; for example, more studies on soil fungal diversity have been carried out in habitats like Cerrado and Caatinga than in Chaco. We observed that in the last few years and due to the development of molecular biology tools, the research work on the soil fungal community has increased considerably. We performed a review of manuscripts in the major publishers (Springer, Scielo, Wiley-Blackwell, Taylor and Francis, Elsevier) in the last ten years. We used the following as key words: fungi, soil, diversity, South America, Cerrado, Caatinga, Chaco, Neotropical dry forests. In this review, we decided to leave out the mycorrhizae since its relevance deserves a separate review.

The aim of this review is to compile the few studies available on soil fungal communities in NTDFs drawing special attention to the seasonally NDTF (NTSDFs) according to Pennington et al., ${ }^{10}$ CalvoRodriguez et al., ${ }^{7}$ published an interesting review about the information available which is currently available about NTDFs; however, in this manuscript the seasonally NTDFs are not taken into consideration. For this reason we have revised not only the principal international journals but also the local ones to detect the fungal diversity loss due to the expansion of the agricultural frontier in the last ten years. It is known that the soil fungal community is being modified by land use, so in agreement with Bissett et al., ${ }^{33}$ we consider that these changes could be used as potential soil structure and functionality indicators.

\section{Seasonally NTDFs}

The present rainfall in NTSDFs is less than $1600 \mathrm{~mm} /$ year and concentrated in 5-6 months a year. During the dry season the prevalent vegetation is deciduous, and in the driest areas succulent and evergreen species prevail. In South America, NTSDFs can be divided according to Pennington et al., ${ }^{10,34}$ and they suggested the presence of different dry-forests based on the tree-dominates composition. The first one, Cerrado, is represented by the Brazilian savanna which is known as the seasonally Neotropical dry forest according to Miles et al., ${ }^{11}$ The second region is Caatinga, which is considered a semiarid region of thorny woodlands in the northeast of Brazil. The last region is Chaco, which covers some areas of western Matto Grosoo and areas of Argentina, Bolivia and Paraguay. As a subtropical extension of temperate vegetation, Chaco, was described as a region with fertile soils, closed canopy, with few grasses and forests with annual frosts by Pennington et al., ${ }^{10,34}$ In the same way Lima et al., ${ }^{35}$ called this area the American Corridor of seasonally dry vegetation (SACSV). Lima et al., ${ }^{36}$ in agreement with other authors suggested that this area has been poorly studied compared to tropical dry forests. The main characteristics of SACSV are the harsh dry season and only one period of rainfall. During several years the studies on these areas have been developed especially in plants, soil carbon and ecosystem services. ${ }^{10,34,35,37-39}$

In the last years, studies on microbial ecology have increased in these areas. Their main objectives among others were a) evaluation of loss diversity, b) impact of anthropogenic management, c) forest clearance and d) functionality of soil community.

\section{Cerrado}

Among the most relevant studies, Pereira de Castro et al., ${ }^{40}$ studied the soil fungal composition in native and modified lands. They suggested that the anthropogenic actions reduce fungal diversity by $50 \%$. Over the last years, Pereira de Castro et al., (2016) suggested that the main source of diversity variation was the seasonal patterns of soil water uptake. They observed that the abundance of yeast and Agaricomycotina decreased as soil moisture increased in Cerrado. In soybean soils and Cerradosensustricto Basidiomycetes showed a positive correlation with soil moisture, but a negative correlation in Cerradodenso and gallery forest. The diversity index values suggested by Ferreira de Araujo et al., ${ }^{41}$ were higher than the ones shown by 53 . Pereira de Castro et al., ${ }^{42}$ and a higher fungal diversity was observed in campo graminoide than in Cerrado forests. In addition, several studies have shown that structural changes in the fungal community were in response to different soil managements. Fracetto et al., ${ }^{43}$ observed that the most abundant phyla were Zygomycota in agricultural soils and primary forest, while the Basidiomycota were more abundant in pasture soils. Recently, Valadares-Pereira et al., ${ }^{44}$ distinguished two different soil fungal communities among soybean soil and Cerrado vegetation. They suggested that these differences were due to soil chemical properties. In summary, the fungal community structure responds to different sources of variation such as vegetation, chemical and environmental conditions. The principal results obtained showed a loss of diversity in modified soils by agricultural management as a result of the expansion agricultural frontier.

\section{Caatinga}

Pennington et al., ${ }^{10}$ and Prado et al., ${ }^{45}$ suggested dividing this area in subregions according to different environmental conditions. Caatinga is an exclusive Brazilian biome having been cleared for many years, which has resulted in a decreasing plant biomass production. This has led to changes in soil interactions and biodiversity losses ${ }^{45}$ Few studies have been carried out on soil fungal diversity in this place. ${ }^{46-51}$ Over the last years, Oliveira et al. ${ }^{46}$ and Cruz et al. ${ }^{49}$ have reported some results that have increased our knowledge about mycological diversity in dry environments. Cruz et al. ${ }^{49}$ noticed high abundance of the genus Penicillium and detected great richness values suggesting that a great number of species are adapted to low moisture content. Likewise, Oliveira et al., ${ }^{46}$ observed that Aspergillus and Penicillium are the most abundant genera and suggested that abiotic factors are the main source of variation in community structures. Moreover, the studies on soil fungal diversity allowed us to detect new fungal species isolated from Caatinga soils. ${ }^{52,53}$ Nascimento-Barbosa et al., ${ }^{50}$ found that diversity and distribution of Aspergillus and Penicillium were directly affected by climate, vegetation and soil type and they pointed out that the loss of diversity was due to widespread disturbance.

In a recent study, Cruz et al., ${ }^{51}$ identified the genus Aspergillus as the most abundant isolation in some anthropic areas more than others and explained that fungal communities have changed due to anthropization.

\section{Chaco}

Schinopsis forests (Chaco forests) are a clear example of the impact of forest clearing due to the expansion of agroindustry in Argentina between 1972 and 2007. ${ }^{15}$ At the same time, these environments are the least represented at the national system of protected areas..$^{54}$ From 6 to 12000 hectares of semiarid "Quebrachales" (Schinopsis forests) have been found completely dismantled, where double cultivation is under irrigation and modern technological package equipment has been developed over Salta, Chaco and Formosa. ${ }^{55}$ The consecuence 
was the expansion of the agricultural frontier towards native forests. This damage produced soil degradation, through an increase in $\mathrm{pH}$ range and loss of organic carbon thus negatively affecting the microbial biomass. ${ }^{56}$

Over the last years, different studies on the effect of agricultural practices on soil fungi have been carried out in Argentina, especially in the agricultural core region. ${ }^{57-60}$ Works on the Schinopsis forests are relevant due to the fact that they are floristically diverse. ${ }^{61}$ However, research on the soil fungal community is scarce. We have found only two works focused on this area: Godeas ${ }^{62}$ and Montecchia et al. ${ }^{56}$ In the first case, the authors used traditional tools of basic mycology and described the isolated species morphologically. They described some ascosporic forms Emericella sp., Talaromyces sp., Sordaria sp., among them. More recently and using molecular tools, Montecchia et al., ${ }^{56}$ proposed that microbial communities were more sensitive to physical-chemical parameters. They observed that microbial communities in cleared and cropped soybean soils were different from the ones in pristine soils. However, their study does not assess the fungal community structure in detail.

Despite the lack of fundamental knowledge about soil fungi in Schinopsis forests and their relevance in ecosystems, we decided to focus on soil fungal diversity in three different soil use types. According to our preliminary results we suggested that the genera Humicola and Absidia were only isolated from forest soils, while Aspergillus and Penicillum were most frequently isolated from cleared soils. In agricultural soils the genus Trichoderma and Paecilomyces were isolated. Besides some pathogenic genera as Fusarium and Alternaria that are typically found in agricultural soils were isolated. These results have shown that the different composition of soil fungal community depends on land use. Although it was difficult to determine any banding pattern according to land use, Montecchia et al., ${ }^{56}$ observed a complex banding pattern expected in these soils using Denaturing Gradient Gel Electrophoresis (DGGE) technique. However, our preliminary results showed a complex banding profile in soil fungal community using DGGE. Therefore, we suggested using a different set of primer to obtain a clear profile..$^{23,43,63}$ The DGGE provides a quick way of looking at biodiversity in a microbial sample and enables us to sequence bands of interest in order to confirm their identity.

\section{Potential use of fungal diversity as "biological alert"}

Among the major factors that modify the structure and activities of the soil microbial community could be mentioned: moisture, temperature, $\mathrm{pH}$, organic soil material content, nutrient availability ${ }^{64}$ and others that may shape them in an indirect way such as latitude, regional weather, texture and soil management, seasons and the vegetation of the place. ${ }^{65}$ The estimations of soil fungal diversity could be used as potential indicators of disturbance or of different anthropogenic uses. ${ }^{29}$ In rainforest soils, Vera et al. ${ }^{66}$ have observed that changes in land use may lead to changes in soil organic matter and consequently affect fungal community. Martínez et al., ${ }^{67}$ observed that the community structure allowed us to differentiate the pristine forests of Nothofagus in Tierra del Fuego.

Over the last decade, the PCR quantitative (qPCR) has emerged as a valuable tool for studying microbial communities in soil, water and air, opening new opportunities to investigate the changes in gene expression in response to pathogen and antagonist fungi. ${ }^{68}$ This tool allows identifying functionality of fungal communities in different types of soil ${ }^{69}$ as well as community structure of Basidiomycota,

\section{Ascomycota and Zygomycota phyla. ${ }^{70,71}$}

No studies using qPCR in Schinopsis forests in Argentina have been found. The only metagenomic survey in Argentinean soils was carried out by Rascovan et al., ${ }^{72}$ concerning how agricultural practices affect soil microbial communities in the Pampean region. In that study $27 \%$ of the Eukarya organisms identified were Fungi. Their conclusion was that water availability associated with geographic differences was the first driver that modified the microbial community and the second one was land use.

\section{Conclusion and perspectives}

Subtropical seasonally dry forests in South America have become systems under different degree of degradation and this is likely to continue because of the expansion of the agricultural frontier. The Chaco forest is regarded as a biodiversity reservoir and it is considered abiological corridor according to Admistración Argentina de Parques Nacionales. ${ }^{73}$ However, only $9 \%$ of the Gran Chaco is protected. ${ }^{74}$

After analyzing the studies available we observed that the most studied areas in the SNDF are Cerrado and Caatinga in terms of structure of fungal communities, and there are more specific studies about Aspergillus and Penicillium. On the other hand, research developed in Chaco is related to the diversity of woody plant species, their distribution and the impact of patch size due to the advance of agro-industry over the past years.

This review highlights the lack of studies on the Schinopsis dry forests soils, so it is deemed necessary to carry out integral studies which include soil fungal communities to provide guidelines on sustainable soil management. This scenario would promote a holistic point of view of the environmental system that could demonstrate the need for new protection and conservation policies since forests are a social good. While some agricultural practices can lead to the degradation of the microbial habitat and reduction of the soil health, sustainable agriculture could be an alternative to the physical, chemical and biological alteration of soils.

Our review showed that Schinopsis dry forests have been scarcely studied so far. Therefore, we propose that future research should focus on the knowledge of plant diversity, soil chemical properties, among other factors, which affect the fungal community structure and function. This point reinforces the fact that only by conducting integral studies a complete understanding of dry forests will be achieved.

\section{Acknowledgements}

We thank Prof. M. Oyarzabal for English assistance. This work was supported by funding from the PIP -CONICET 2014-2016 COD: 112-20130100280 and by the Individual Doctoral scholarship of CONICET.

\section{Conflict of interest}

Authors declare there is no conflict of interest in publishing the article.

\section{References}

1. World Wildlife Foundation. Terrestrial Ecoregions. WWF; 2018.

2. Fajardo L, González V, Nassar J, et al. Tropical Dry Forests of Venezuela Characterization and Current Conservation. Status Biotropica. 2005;37(4):531-546. 
3. Pan Y, Birdsey RA, Fang J, et al. A large and persistent carbon sink in the world's forests. Science. 2010;333(6045):988-933.

4. Van der, Werf GR, Morton DC, et al. $\mathrm{CO}_{2}$ emissions from forest loss. Nature geoscience. 2009;2:737-739.

5. Becknell JM, Kucek LK, Powers JS, et al. Aboveground biomass in mature and secondary seasonally dry tropical forests a literature review and global. Ecology Evolution and Behavior. 2012;276:88-95.

6. Calvo Rodríguez S, Sanchez Azofeifa AG, Duran SM, et al. Assessing ecosystem services in Neotropical dry forests a systematic review. EnvironmentalConservation. 2016;44(1):1-10.

7. United Nations. Non-legally binding instrument on all types of forests. $62^{\circ}$ General Assembly. UN; 2007.

8. Sánchez-Azofeifa AG, Quesada M, Rodríguez J P, et al. Research Priorities for Neotropical Dry Forests. Biotropica. 2005;37(4):477-485.

9. Balvanera P, Uriarte M, Almeida-Leñero L, et al. Ecosystem services research in Latin America the state of the art. Ecosystem Services. $2012 ; 2: 56-70$

10. Pennington RT, Prado DE, Pendry CA, Neotropical seasonally dry forests and Quaternary vegetation changes. Journal of Biogeography. 2000;27(2):261-273.

11. Miles L, Newton AC, DeFries RS, et al. A global overview of the conservation status of tropical dry forests. Journal of Biogeography. 2006;33(3):491-505

12. Salvador V. Capítulo 7: Impactosobre el hábitat. En: Viglizzo EF, Jobbágy E, Editors. Expansión de la Frontera Agropecuariaen Argentina y su Impacto Ecología-Ambiental. La Pampa, Argentina: Ediciones Instituto Nacional de Tecnología Agropecuaria; 2010. p. 43-46.

13. Goytia SY. Análisis de losefectos que incidenen el cambio del uso de sueloen el Departamento de Comandante Fernández - Provincia de Chaco. Tesis de Maestría (Maestríaen Teledetección y Sistemas de Información Geográfica). Facultad de Agronomía, Universidad Nacional del Centro de la Provincia de Buenos Aires; 2014.

14. Caruso H, Camardelli M, Miranda S, Efecto del método de desmonte sobre los indicadores de calidad del suelo y la condición de las pasturasen el Chaco. semiáridosalteño. Agriscienta. 2012;29(2):99-105.

15. Gasparri NI, Grau HR, Deforestation and fragmentation of Chaco dry forest in NW Argentina. Forest Ecology and Management, 2009;258(6):913-921.

16. Grau HR, Gaspari NI Aide TM, Agriculture expansion and deforestation in seasonally dry forests of north-west Argentina. Environmental Conservation. 2005;32(2):140-148.

17. Marie D, Zhu F, Balagué V, et al. Eukaryotic picoplankton communities of the Mediterranean sea in summer assessed by molecular approaches (DGGE, TGGE, QPCR). FEMS Microbiology and Ecology. 2006;55(3):403-415.

18. Tedersoo L, Bahram M, Põlme S, et al.Global diversity and geography of soil fungi. Science. 2014;346(6213):1256688.

19. Hibbett DH, Binder M, Bischoff JF, et al. A higher-level phylogenetic classification of the Fungi. Mycological research. 2007;111(5):509-547.

20. Hawksworth DL, Lücking R. Fungal Diversity Revisited: 2.2 to 3.8 Million Species. Microbiological Spectrum. 2017;5(4):0052.

21. Wallander H, Nilson LO, Hagerbeg D, et al. Estimation of the biomass and seasonal growth of external mycelium of ectomycorrhizal fungi in the field. New Phytologist. 2001;3(151):753-760.

22. Cabello M, Arambarri A. Diversity in soil fungi from undisturbed and disturbed Celtistala and Scutia buxifolia forests in the eastern Buenos
Aires province (Argentina). Microbiological Research. 2002;157(2):115125 .

23. Anderson IC, Campbell CD, Prosser JI. Diversity of fungi in organic soils under a moorland- Scots pine (Pinus sylvestris L.) gradient. Environmental Microbiology. 2003;5(11):121-1132.

24. Paillet Y, Bergès L, Hjältén J, et al. Biodiversity Differences between Managed and Unmanaged Forests: Meta-Analysis of Species Richness in Europe. Conservation Biology. 2010;24(1):101-112.

25. Shivakumar PB, Thippeswamy B, Thirumalesh BV, et al. Diversity of soil fungi in dry deciduous forest of Bhadra Wildlife Sanctuary, Western Ghats of southern India. Journal of Forestry Research. 2012;23(4):631-640.

26. Zhao J, Wang X, Shao Y, et al. Effects of vegetation removal on soil properties and decomposer organisms. Soil Biology \& Biochemistry. 2011;43(5):954-960.

27. LeBlanc N, Kinkel LL, Kistler HC. Soil fungal communities respond to grassland plant community richness and soil edaphics. Microbiology and Ecology. 2015;70(1):188-195.

28. Reininger V, Martínez-García LB, Sanderson L, et al. Composition of fungal soil communities varies with plant abundance and geographic origin. AOB Plants. 2015;7:plv110.

29. Jangid K, Williams MA, Franzluebbers AJ, et al. Land-use history has a stronger impact on soil microbial community composition than aboveground vegetation and soil properties. Soil Biology and Biochemistry. 2011;43(10):2184-2193.

30. Shen R, Xu M, Li R, et al. Spatial variability of soil microbial biomass and its relationships with edaphic, vegetational and climatic factors in the Three-River Headwaters region on Qinghai-Tibetan Plateau. Applied Soil Ecology. 2015;95:191-203.

31. Waldrop MP, Zak DR, Blackwood CB, et al. Resource availability controls fungal diversity across a plant diversity gradient. Ecology Letter. 2006;9(10):1127-1135.

32. Pötzelsberger E, Hasenauer H. Soil change after 50 years of converting Norway spruce dominated age class into single tree selection forests. Forest Ecology and Management. 2015;338:176-182.

33. Bissett A, Richardson AE, Baker G, et al. Long-term land use effects on soil microbial community structure and function. Applied Soil Ecology. 2011;51:66-78.

34. Pennington RT, Lavin M, Prado DE, et al. Historical climate change and speciation: Neotropical seasonally dry forest plants show patterns of both Tertiary and Quaternary diversification. Philosophical Transactions of the Royal Society of London. 2004;359(1443):515-537.

35. Lima RB, Bufalino L, Alves Junior FT, et al. Diameter distribution in a Brazilian tropical dry forests domain: predictions for the stand and species. Anais da Academia Brasileira de Ciências. 2017;2(89):1189-1203.

36. Lima JR, Tozzi AMGA, Mansano VF. A checklist of woody Leguminosae in the South American corridor of dry vegetation. Phytotaxa. 2015;207(1):1-38

37. Ferrero ME, Villalba R, De Membiela M, et al. Tree-growth responses across environmental gradients in subtropical Argentinean forests. PlantEcology. 2013;214(11):1321-1334.

38. Banda K, Delgado-Salinas A, Dexter KG, et al. Plant diversity patterns in neotropical dry forests and their conservation implications. Science. 2016;353(6306):1383-1387.

39. Conti G, Kowaljow E, Baptist F, et al. Altered soil carbon dynamics under different land-use regimes in subtropical seasonally-dry forests of central Argentina. PlantSoil. 2016;403(1-2):375-387.

40. Pereira de Castro A, Ferraz Quirino B, Pappas G, et al. Diversity of soil 
fungal communities of Cerrado and its closely surrounding agriculture Welds. Arch Microbiology Journal. 2008;190(2):129-139.

41. Ferreira de Araujo AD, MelgaçoBezerra W, dos Santos VM, et al. Fungal diversity in soils across a gradient of preserved Brazilian Cerrado. Journal of Microbiology. 2017;55(4):273-279.

42. Pereira de Castro A, Silveira Sartori da Silva MR, Ferraz Quirino B, et al. Microbial diversity in Cerrado Biome (Neotropical Savanna) soils. PlosOne. 2016;11(2):e0148785.

43. Fracetto GGM, Azevedo LCB, Fracetto FJC, et al. Impact of Amazon land use on the community of soil fungi. Scientia Agricola. 2012;70(2):59-67.

44. Valadares-Pereira AA, Martins Oliveira ECA, Navarrete AA, et al. Fungal community structure as an indicator of soil agricultural management effects in the cerrado. Revista Brazileira de Ciencias do Solo. 2017;41:e0160489.

45. Prado DE. Seasonally dry forests of tropical South America: from forgotten ecosystems to a new phytogeographic unit. Edinburgh Journal of Botany. 2000;57(3):437-461.

46. Oliveira LG, Cavalcanti MAQ, Fernandes MJS, et al. Diversity of filamentous fungi isolated from the soil in the semiarid area, Pernambuco, Brazil. Journal of Arid Environments. 2013;95:49-54.

47. Cavalcanti MAQ, Oliveira LG, Fernandes MJ, et al. Fungos filamentosos isolados do solo em municipios naregião Xingó, Brasil. ActaBotánica Brasilica. 2006;20(4):831-837.

48. Santiago ALCMA, Souza-Motta CM. Mucorales isolados do Solo de Mineração de Cobre e Produção de Amilase e Inulinase. Acta Botanica Brasilica. 2006:20(3):641-647.

49. Cruz R, Silva de Lima J, Cordoville Fonseca J, et al. Diversity of Filamentous Fungi of Area from Brazilian Caatinga and HighLevel Tannase Production Using Mango (Mangifera indica L.) and Surinam Cherry (Eugenia uniflora L.) Leaves under SSF. Advances in Microbiology, 2013;3(8A):52-60.

50. Nascimento-Barbosa R, Pereira Bezerra JD, Oller Costa PM, et al. Aspergillus and Penicillium (Eurotiales: Trichocomaceae) in soils of the Brazilian tropical dry forest: diversity in an area of environmental preservation. Revista de Biología Tropical. 2016;64(1):45-53.

51. Cruz R, Sousa Ramos SM, Cordoville Fonseca J, et al. Anthropization Effects on the Filamentous Fungal Community of the Brazilian Catimbau National Park. Revista Brasilera de Ciencias do Solo. 2017;4:e0160373.

52. Matsuzawa T, Campos Takaki GM, Yaguchi T, et al. Two new species of Aspergillus section Fumigati isolated from caatinga soil in the State of Pernambuco, Brazil. Mycoscience. 2014;55(2):79-88.

53. Matsuzawa T, Campos Takaki GM, Yaguchi T, et al. Aspergillus arcoverdensis, a new species of Aspergillus section Fumigati isolated from caatinga soil in State of Pernambuco, Brazil. Mycoscience. 2015;56(2):123-131.

54. Izquierdo AE, Grau NI. Agriculture adjustment, land-use transition and protected areas in Northwestern Argentina. Journal of Environmental Management. 2009;90(2):858-865.

55. Di Paola MM. Expansión de la fronteraagropecuaria. Apuntes Agroeconómicos. 2013;4(3).

56. Montecchia MS, Correa OS, Soria MA, et al. Multivariate approach to charcaterizing soil microbial communities in pristine and agricultural sites in Northwest Argentina. Applied Soil Ecology. 2011;47(3):176-183.

57. Lori GA, Sisterna MN, Sarandón SJ, et al. Fusarium head bright in wheat: Impact of tillage and other agronomic practices under natural infection. Crop Protection. 2009;28(6):495-502.
58. Silvestro LB, Stenglein SA, Forjan H, et al. Occurrence and distribution of soil Fusarium species under wheat crop in zero tillage. Journal Spanish of Agricultural Research. 2013;11(1):72-79.

59. Silvestro LB, Biganzoli F, Stenglein SA, et al. Mixed cropping regime promote the soil fungal community under zero tillage. Antonie van Leeuwenhoek. 2018; p. 1-10.

60. Gómez RP, Aulicino MB, Mónaco CI, et al. Impact of different cropping conditions and tillage practices on the soil fungal abundance of a Phaeozem luvico. Spanish Journal of Agricultural Research. 2015;13(2):e1102.

61. Lewis JP, Pire EF, Barberis IM. Structure, physiognomy and floristic composition of a Schinopsis balansae (Anacardiaceae) forest in the Southern Chaco, Argentina. Revista de Biología Tropical. 1997;45(3):1013-1018.

62. Godeas AM. Micoflora del suelo de la Argentina. I Algunas formas ascospóricas de la región Chaqueña. Mycopathologia et mycologia applicata. 1972;46(3):189-204.

63. Marshal MN, Cocolin L, Mills DA, et al. Evaluation of PCR primers for denaturating gradient gel electrophoresis analysis of fungal communities in compost. Journal of Applied Microbiology. 2003;95(5):934-948.

64. Kaisermann A, Maron PA, Beaumelle L, et al. Fungal communities are more sensitive indicators to non-extreme soil moisture variations than bacterial communities. Applied Soil Ecology. 2015;86:158-164.

65. Brockett BFT, Prescott CE, Grayston SJ. Soil moisture is the major factor influencing microbial community structure and enzyme activities across seven biogeoclimatic zones in western Canada. Soil Biology and Biochemistry. 2012;44(1):9-20.

66. Vera M, Sierra M, Diez M, et al. Deforestation and land use effects on micromorphological and fertility changes in acid rainforest soils in Venezuelan Andes. Soil Tillage and Research. 2007;97(2):184-194.

67. Martínez AE, Chiocchio VM, Godeas AM. Hyphomycetes celulolíticos en suelos de bosques de Nothofagus, Tierra del Fuego. Gayana Botanica. 2001;58(2):123-132.

68. Schena L, Nigro F, Ippolito A, et al. Real-time quantitative PCR: a new technology to detect and study phytopathogenic and antagonistic fungi. European Journal of Plant Pathology. 2004;110(9):893-908.

69. Anderson IC, Parkin PI. Detection of active soil fungi by RT-PCR amplification of precursor r-RNA molecules. Journal of Microbiological Methods. 2006;68(2):248-253.

70. Manter DK, Vivanco JM. Use of the ITS primers, ITS1F and ITS4, to characterize fungal abundance and diversity in mixed-template samples by qPCR and length heterogeneity analysis. Journal of Microbiology Methods. 2007;71(1):7-14.

71. Hata DJ, Buckwalter SP, Pritt BS, et al. Real-Time PCR method for detection of Zygomycetes. Journal of Clinical Microbiology. 2008;46(7):2353-2358.

72. Rascovan N, Carbonetto B, Revale S, et al. The PAMPA dataset: a metagenomic survey of microbial communities in Argentinean pampean soils. Microbiome. 2013;1(1):21.

73. Administración de Parques Nacionales de Argentina. Corredores ecológicos para el Chaco Argentino. Área de Vinculación y Control. Secretaría de Ambiente y Desarrollo Sustentable de la Nación; 2015.

74. Nori J, Torres R, Lescano JN, et al. Protected areas and spatial conservation priorities for endemic vertebrates of the Gran Chaco, one of the most threatened ecoregions of the world. Diversity and Distributions. 2016;22(12),1212-1219. 